\title{
IODP Expedition 307 Drills Cold-Water Coral Mound Along the Irish Continental Margin
}

\author{
by Timothy G. Ferdelman, Akihiro Kano, Trevor Williams, \\ and the IODP Expedition 307 Scientists
}

\section{Introduction}

Over the past decade, oceanographic and geophysical surveys along the slope of the Porcupine Seabight off the southwestern continental margin of Ireland have identified upwards of a thousand enigmatic mound-like structures (Figs. 1 and 2). The mounds of the Porcupine Seabight rise from the seafloor in water depths of 600-900 $\mathrm{m}$ and form impressive conical bodies several kilometers wide and up to $200 \mathrm{~m}$ high. Although a few mounds such as Thérèse Mound and Galway Mound are covered by a thriving thicket of coldwater corals, most mound tops and flanks are covered by dead coral rubble or are entirely buried by sediment (De Mol et al., 2002; Fig. 2, Beyer et al., 2003). Lophelia pertusa (Fig. 3) and Madrepora oculata are the most prominent cold-water corals growing without photosynthetic symbionts. The widespread discovery of large and numerous coral-bearing banks and the association of these corals with the mounds have generated significant interest as to the composition, origin and development of these mound structures. (internal control) (Hovland et al., 1998; Henriet et al., 2001). The oceanographic or environmental hypothesis states that the two most important conditions for stimulating mound development are (1) strong, nutrient-rich currents that provide suspended food to the filter-feeding corals, sweep the polyps clean of detritus and inhibit sediment burial, and (2) a stable substrate for settlement of coral larvae (Frederiksen et al., 1992). Strong bottom currents in the Belgica mound province, resulting from internal tidal wave effects at the boundary between Mediterranean Outflow Water and East North Atlantic Water, provide the suspended nutrients for filter-feeding cold-water corals.

The hydrocarbon seepage hypothesis was first proposed by Hovland et al. (1998), who suggested that hydrocarbon seepage may promote favorable development conditions for deep-sea corals. Elevated dissolved inorganic carbon concentrations derived from the microbially mediated oxidation of light hydrocarbons-in particular methane-are conducive to skeletal accretion and for submarine lithification. Based

Challenger Mound, in the Belgica mound province, has an elongated shape oriented along a north-northeast to south-southwest axis and is partially buried under Pleistocene drift sediments. In high-resolution seismic profiles the mounds appear to root on an erosion surface (van Rooij et al., 2003). During IODP Expedition 307 the Challenger Mound in the Porcupine Seabight was drilled with the goal of unveiling the origin and depositional processes within these intriguing sedimentary structures. Challenger Mound, unlike its near neighbors the Thérèse and Galway mounds, has little to no live coral coverage and, therefore, was chosen as the main target for drilling activities, so that no living ecosystem would be disturbed.

\section{External vs. Internal Control on Mound Development}

Two theories have been forwarded to explain the initiation and growth of these impressive structures: (1) oceanographic and paleoenvironmental conditions control mound initiation and growth (external control), and (2) hydrocarbon seepage initiates microbial-induced carbonate formation and indirectly fuels coral growth

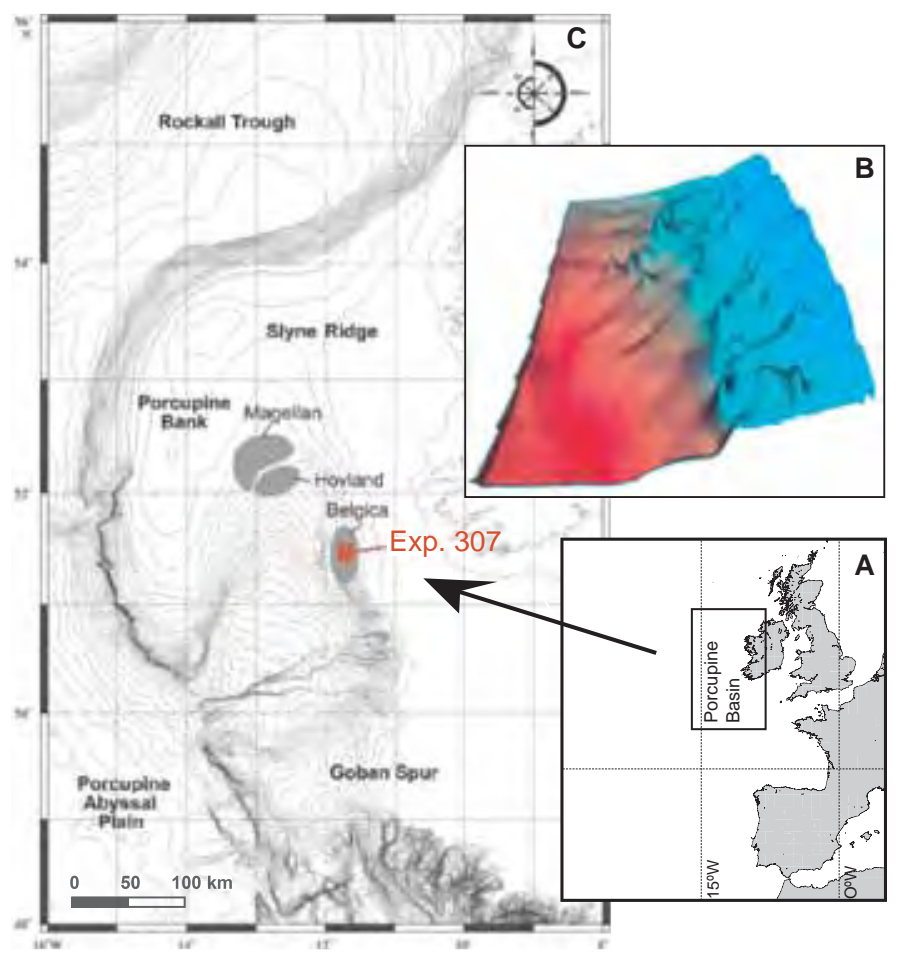

Figure 1. Location of Porcupine Seabight and IODP Expedition 307 operations area. 


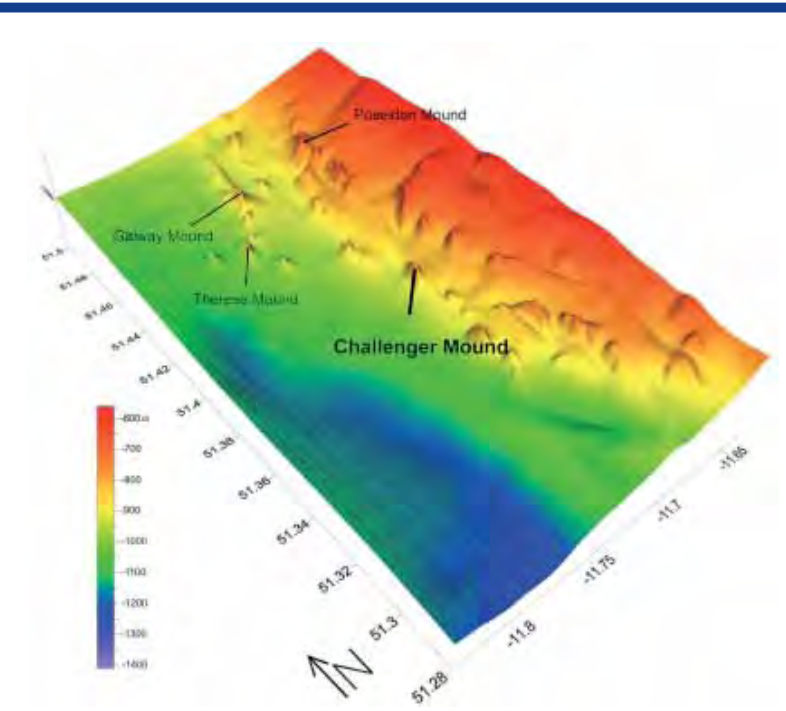

Figure 2. Multibeam bathymetry of Belgic mound province on eastern slope of Porcupine Seabight (after Beyer et al., 2003).

on seismic profiling, Henriet et al. (2002) suggested a fourstage developmental model applicable to Challenger Mound. The initial stage may have related to fluid venting and authigenic carbonate precipitation, which provided a hardground for corals to colonize. In the second stage, the settling of corals on the hardground in connection with microbially induced carbonate precipitation catalyzed mound growth. Further growth of corals developed a carbonate mound in the third stage. Pelagic ooze and current-transported siliciclastic sediments were trapped in the framework of branching corals. In the final stage, Challenger Mound was buried asymmetrically by drift sediments.

Challenger Mound is one of thousands of mound structures in the Porcupine Seabight and the first to be scientifically cored deeper than $12 \mathrm{~m}$, so drilling this structure was true exploration. Did it contain corals deeper within the mound and to the base? Is it a carbonate mud mound composed of microbial automicrite similar to structures that occur ubiquitously in Paleozoic-Mesozoic strata worldwide? On what type of surface did the mound root? To answer these and other questions, we successfully drilled three sites in an off-mound-mound-upper-slope transect (Fig. 4), within just twelve days of science operations onboard the JOIDES Resolution. The sites were chosen (1) to constrain the stratigraphic framework of the slope and mound system, (2) to identify and correlate regional erosional surfaces identified in seismics and (3) to investigate the hypothesized presence of hydrocarbons as the energy source for mound nucleation and sustained growth in a microbe-dominated environment.

\section{Drilling and Sampling Challenges}

IODP Expedition 307 faced a number of new and interesting operational and scientific challenges. The lead time from scheduling the expedition to sailing was extremely short (less than five months). The expedition was planned for only ten days of science operations with a short transit from
Dublin, Ireland to the drilling sites. Fortunately, the weather was fair and two extra days were gained from a shortened port call in Dublin harbor. In these twelve days it was possible to complete the project and recover nearly 1400 meters of sediment from eleven holes at three sites. This included a fivehole transect at site 1317 across the western flank of Challenger Mound itself, logging on all sites, and a vertical seismic profile taken within the mound.

The expedition employed an integrated sedimentological, geochemical, and microbiological approach. Each specialty group was aware of the value of their analyses to the other groups and the connections between parameters such as microbial action, interstitial water chemistry and diagenetic alteration of the sediments. As much as $1.5-\mathrm{m}$ core sections were assigned for microbiological sampling and forwarded to the temporary cold lab established in the ship's hold for sampling of DNA, lipids, cell enumeration and whole-round cores for experimental work. All cores, including a number of sections assigned to microbiology, were run through the fast-track magnetic susceptibility meter without problems.

Expedition 307 faced the technical challenge of how to split and curate coral-bearing sediment. Conventional methods of core-splitting, using both wire-cutter and saw, resulted in fragmenting the coral, with coral pieces being dragged down the split core surface and degrading the sediment structure. In the core laboratory, a new technique was developed for splitting coral-bearing cores in an unlithified matrix. All core sections from Hole U1317C were split by saw only after being frozen to $-50^{\circ} \mathrm{C}$ for 48 hours. Apart from some centimeter-long freeze-cracks on the split core face, the coral structure was beautifully preserved, and it was unanimously agreed that this method produced the best results (Fig. 5). Holes U1317A and U1317D were split using the conventional saw, so that the sedimentologists could describe at least one full stratigraphic section. Holes U1317B and U1317E remained unopened onboard and awaited freezesplitting at College Station, Texas, U.S.A. Additionally, selected coral-bearing cores were sent to Erlangen, Germany, for highresolution computertomography scanning. A two-week description and sampling party in October 2005 at the Bremen Core Repository (Germany), concluded the initial science activities of IODP Expedition 307.

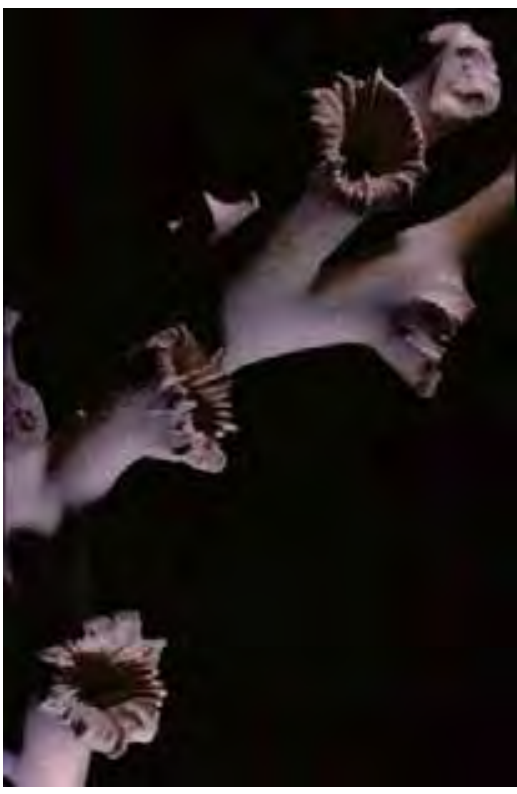

Figure 3. Micro-image of Lophelia pertusa. 


\section{Challenger Mound is a Coral Bearing Build-up}

Drilling at Site U1317 revealed that the Challenger Mound does indeed rest on a sharp erosional surface (Fig. 6) corresponding to the one identified in seismic profiles (Fig. 4). This surface cuts across the lower lying Miocene-Pliocene siliciclastic sequence (seismic unit P1). Sediments below this erosional surface consist of glauconitic and silty sandstone drift deposits of Miocene age. The Miocene strata end abruptly in the firm ground that underlies the Pleistocene mound sequence. Initial magnetostratigraphic and biostratigraphic results suggest that the hiatus between the two sequences spans at least 1.65 million years. While the mound appears to be Pleistocene in age, the mound flanks are draped by comparably younger Pleistocene $(<0.26 \mathrm{Ma})$ silty clay deposits that contain frequent dropstones.

The Challenger Mound itself is dominated by unlithified coral-bearing (Lophelia pertusa) floatstone and rudstone. The muddy matrix of the sediment consists largely of terrigenous clay and calcareous nannofossils, including reworked Cretaceous species. The micritic carbonate component of the mound consists almost completely of coccolithophorids. The mound sequence shows pronounced recurring cycles on a scale of one to several meters. The cycles exhibit distinct changes in carbonate content and generally consist of floatstone overlain by rudstone interbedded with wackestone. The cycles found in the mound succession are possibly associated with the Pleistocene glacial-interglacial cycles; however, preliminary investigation of foraminifera assemblages shows rare occurrences of cold-water species and suggests that the mound sequence might have formed main-ly during interglacial periods.

Figure 4 shows the first interpretation of the lithostratigraphy and age model superimposed on the seismic interpretation. Based on this schematic overview, the mound initiated on the erosion surface that separates seismic units $\mathrm{P} 1$ and $\mathrm{P} 2$ from unit P3. The timing of this erosional episode is still unclear based on initial shipboard data, but it ten- tatively correlates to an early Pliocene erosional episode in the nearby Rockall Basin (DeMol et al., 2002; Van Rooij et al., 2003). Calcareous nannofossil biostratigraphy indicates that deposition of the 150-m thick coral-bearing mound section started after $1.95 \mathrm{Ma}$ and ended before 0.46 Ma. Upper Pleistocene to recent sediments have onlapped and already buried the older Pleistocene mound strata. At present, neither the internal mound structure nor the processes of mound formation and accretion are well understood. Evidence from Site U1316, located $700 \mathrm{~m}$ to the southwest of Challenger Mound, indicates down-slope coral transport (Fig. 7). Relating mound and off-mound successions will be important for answering questions on the growth mechanics, accretion and shedding processes (i.e., vertical and lateral growth vs. verified growth and down-slope shedding). It will also be important to investigate the horizontally contiguous extent of coral growth phases and strata. These questions will be the focus of close examination of the various physical and lithostratigraphic data collected during Expedition 307.

\section{No Role for Hydrocarbon Seepage in the Challenger Mound?}

Significant hydrocarbon seepage is not evident from the lithostratigraphy or from the initial geochemical and microbiological results. Only low to moderate concentrations of methane or ethane $(<2 \mathrm{mM})$ were measured in the mound or

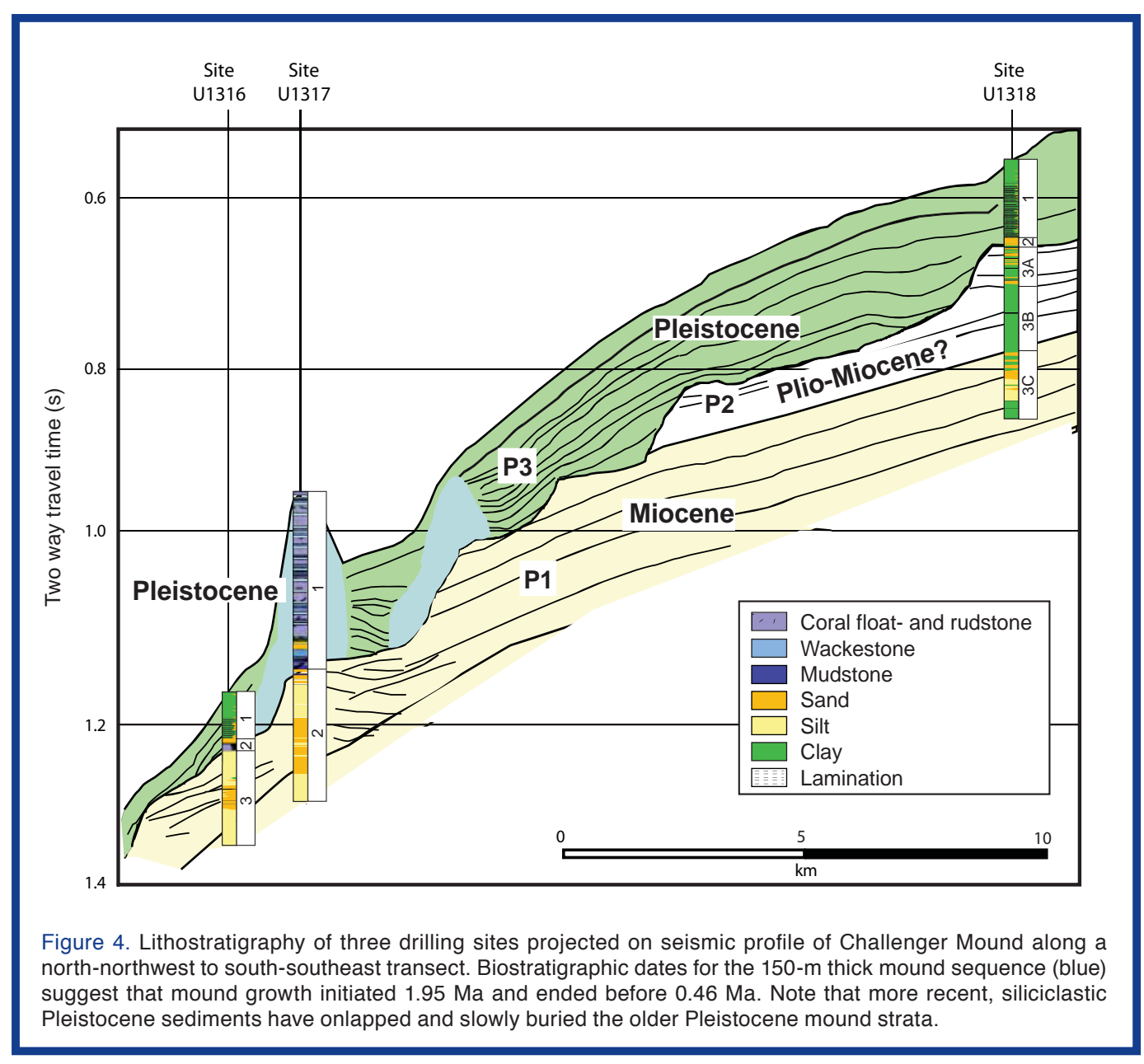




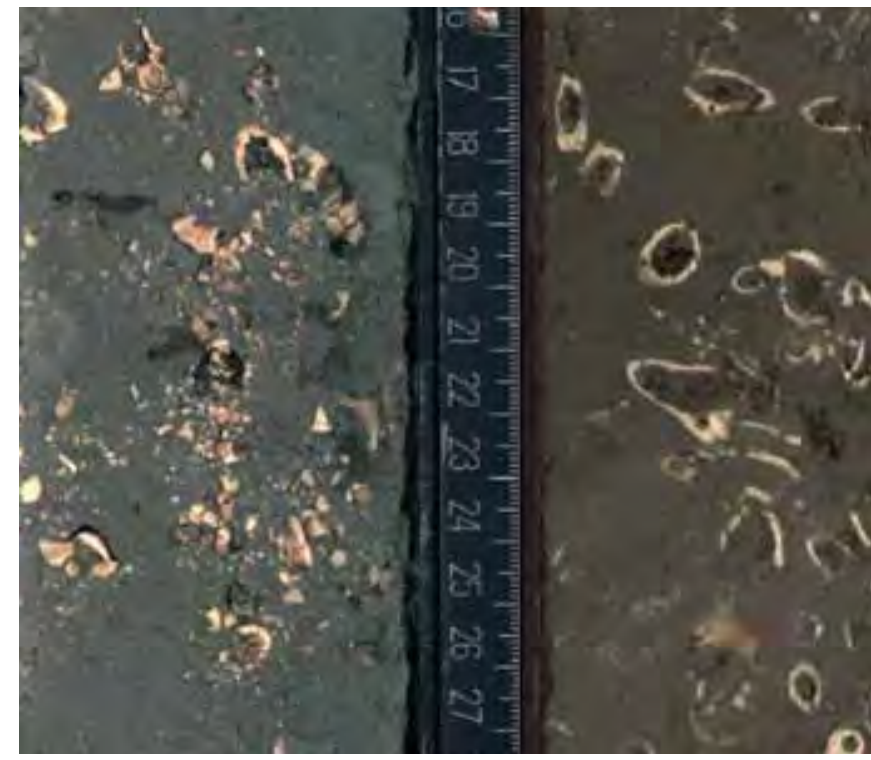

Figure 5. Comparison of cores split with traditional (left) versus freezing and sawing (right) methods.

in the sub-basal mound sediments. At Site U1317 on the Challenger Mound, the methane to sulfate transition was detected in the underlying Miocene silt and sandstones. Although the mound has a sharply defined base, no basal carbonate hardgrounds were observed to suggest microbially induced carbonate precipitation. However, this latter finding awaits confirmation through stable isotope, biomarker and microbiological analyses. Although hydrocarbon seepage may occur in certain mound structures elsewhere in the world (e.g., the Pen Duick structures off the coast off Morocco), our current interpretation of Expedition 307 data suggests that hydrocarbon seepage is not a necessary condition for the development of a coral mound and very likely not for the Belgica mound province in general.

\section{The Microbial Imprint}

Challenger Mound might not be a suitable modern analog for understanding the Phanerozoic mounds of microbial origin; however, fascinating aspects of deep microbial activity at all sites were evident already in the shipboard interstitial-water chemistry and prokaryote distributions. For instance, the subtle intertwining of carbonate-mineral-controlled diagenesis and microbially mediated organic matter decay represents one of the highlights of the geochemical and microbiological investigations on the mound site. Methane, sulfate and alkalinity profiles, as shown in Figure 8, reflect zones of microbially mediated organic decay. Below 150 mbsf, within the zone of sulfate reduction coupled with anaerobic oxidation of methane, increasing dissolved $\mathrm{Ca}^{2+}$ levels and decreasing dissolved $\mathrm{Mg}^{2+}$ levels suggest that dolomite is forming within Miocene sediments below the mound base. Surprisingly, there were significantly more prokaryotic cells in these much deeper and older Miocene sediments than would be expected from their age and depth. They are also present in comparable or greater numbers in the overlying PliocenePleistocene sequences.

Within the mound itself, the curved profiles for sulfate and alkalinity between 0 and $50 \mathrm{mbsf}$ indicate decay of organic matter and consumption of the sulfate mediated by sulfate-reducing bacteria. In addition, an increase in dissolved $\mathrm{Sr}^{2+}$ indicates that aragonite dissolution is releasing strontium into the interstitial water. Over the same depth interval, dissolved $\mathrm{Mg}^{2+}$ also shows a loss, as evidenced in the decreased $\mathrm{Mg}$ concentration (Fig. 8), thus suggesting that dolomite or some other $\mathrm{Ca}-\mathrm{Mg}$ carbonate mineral (e.g., low-Mg calcite or calcian dolomite) is precipitating and removing $\mathrm{Mg}$ from solution. Decomposition of organic matter by sulfate reduction may be driving this process by producing $\mathrm{CO}_{2}$, which enhances aragonite dissolution, and increasing the overall dissolved inorganic carbon concentration. Iterestingly we detected no dissolved hydrogen sulfide that should accumulate in the interstitial water as a product of sulfate reduction. It is very likely that the sulfide reacts with ferric-iron-containing minerals in the siliciclastic fraction and precipitates as iron sulfide minerals, particularly pyrite $\left(\mathrm{FeS}_{2}\right)$. Overall, sulfate reduction coupled with pyrite formation would drive re-precipitation of carbonates as described in the following equation.

$$
\begin{aligned}
& 3 \mathrm{SO}_{4} 2-+6 \mathrm{CH}_{2} \mathrm{O}+2 \mathrm{FeOOH}+\mathrm{Ca}^{2+}+2 \mathrm{Mg}^{2+}+\mathrm{CaCO}_{3} \\
& \Rightarrow \\
& \mathrm{FeS}_{2}+\mathrm{FeS}+4 \mathrm{Ca}_{0.5} \mathrm{Mg}_{0.5} \mathrm{CO}_{3}+3 \mathrm{CO}_{2}+7 \mathrm{H}_{2} \mathrm{O}
\end{aligned}
$$

Lower sulfate, $\mathrm{Ca}^{2+}$ and $\mathrm{Mg}^{2+}$, along with higher alkalinity and $\mathrm{Sr}^{2+}$ concentrations, in Hole U1317E suggest that microbially mediated organic matter decay and carbonate mineral

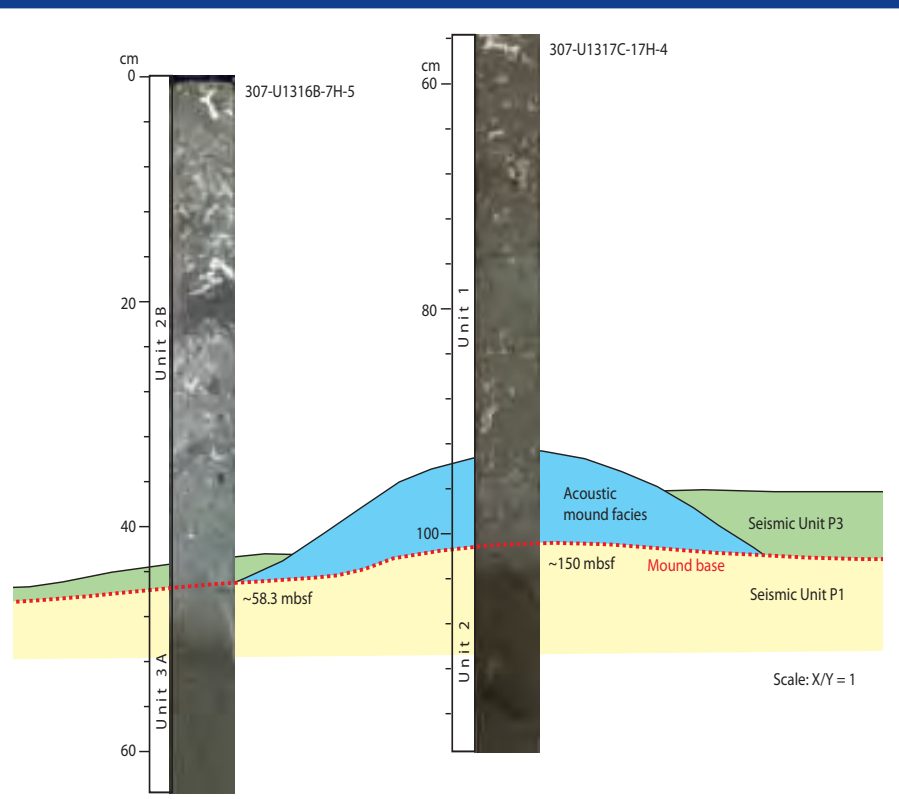

Figure 6. Comparison of mound base core photographs from Sites U1316 and U1317 with schematic representation of the mound. 
diagenesis are more intense at the mound top (Fig. 8), where sediments remain $i$ situ relative to the mound flanks (Holes U1317A-U1317D which are characterized by downslopetransported sediments). The mound facies suggests that there are dark zones of good coral preservation and little lithification alternating with light colored zones of very poor carbonate preservation. It remains to be seen if microbial or

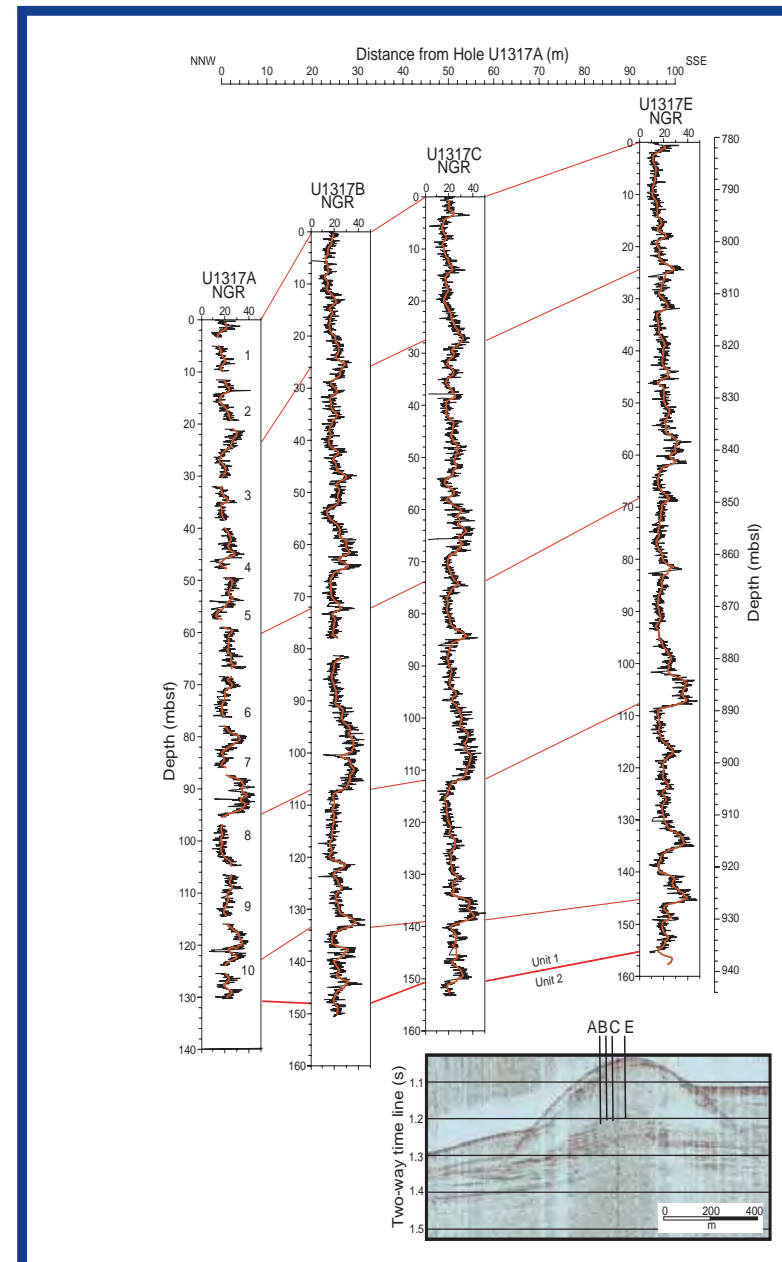

Figure 7. Transect of holes at Site U1317 on the seaward side of Challenger Mound. The natural gamma distributions show the variations in strata that will be used to form a stratigraphic framework for interpreting mound growth. The track data are arranged to reflect the variations in water column depth at each hole. oceanographic factors govern the geochemistry and subsequent carbonate dissolution, re-precipitation and lithification. These answers will provide the basis for understanding how the mound structure is maintained. These interstitial-water chemistry results already provide some insight into the lithification processes and suggest hypotheses for further testing onshore.

\section{Forthcoming Research and Implications}

Results from IODP Expedition 307 demonstrate that unlithified sediments form high and steep-flanked conical structures in a shelf margin setting. One intriguing question is how such structures are stabilized on the seafloor. The presence or absence of a coral framework may be a key to understanding not only the sediment-stabilizing process but also the rapid accretion. Further research will address this and other issues by high-resolution x-ray computer-tomography (CT) scanning of the whole-round core sections from selected horizons. Furthermore, cold-water coral mounds may serve as high-resolution environmental recorders. Based on observations of sediment composition, color and coral preservation, the mound sequence appears to record glacial-interglacial climate changes. Because cold-water corals are sensitive to conditions such as water temperature, nutrient conditions, and current strength, their mineralogy, assemblage, and geochemistry will provide ideal proxy records for studying these changes over time. Cold-water corals grow at rates of up to $25 \mathrm{~mm} \mathrm{yr}^{-1}$, or fast enough to apply the same methods of coral paleoclimatology used for tropical and subtropical reef-forming corals. Analyses of stable isotopes and trace elements are expected to provide temperature and carbon circulation data with sub-annual resolution. Although coral reefs are commonly associated with shallow-water tropical to subtropical regions, cold-water coral bioherms are known from the geological record. Well-known examples include the coral mound communities of the Danian in the chalks at Fakse in Denmark (Bernecker and Wiedrich, 2005) and the Pleistocene St. Paul's Bay Limestone on the island of Rhodes (Titschack and Freiwald, 2005). We are confident that IODP Expedition 307 will pro-

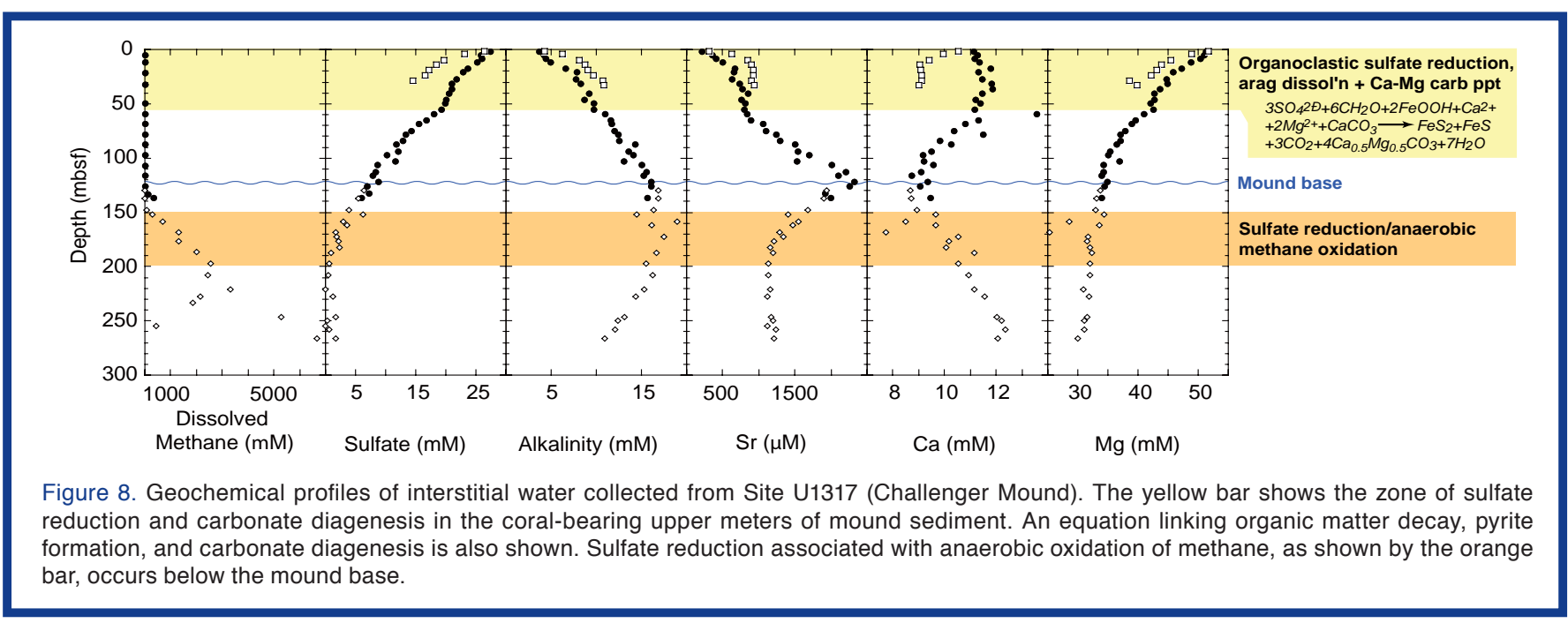


vide insight into the establishment and sustainability of coral-bearing mounds and build-ups in a predominately siliciclastic slope environment, and into the interpretation of these morphologies and facies in seismic profiles and the geological record.

\section{Acknowledgements}

IODP Expedition 307 never could have sailed without the vision, dedication and enthusiasm of Professor Jean-Pierre Henriet, the lead proponent and driving force behind the scientific effort to drill these enigmatic structures. JeanPierre was unable to sail with us but was responsible for much of the pre-expedition preparations and was an indispensable source of advice and insight during and after the expedition. We sincerely thank Eibhlyn Doyle at the Geological Survey of Ireland (GSI) for all of her help and the GSI for graciously hosting our pre-expedition workshop. The success of IODP Expedition 307 lies largely with the extraordinary “can-do" attitude of the JOIDES Resolution IODP staff, the sterling performance of the Transocean crew, and the assistance of the Gulf Coast and Bremen Core Repositories.

\section{IODP Expedition 307 Scientists}

T.G. Ferdelman (Co-Chief Scientist), A. Kano (Co-Chief Scientist), T. Williams (Staff Scientist), K. Abe, M.S. Andres, M. Bjaerger, E.L. Browning, B.A. Cragg, B. De Mol, B. Dorschel, A. Foubert, T.D. Frank, Y. Fuwa, P. Gaillot, J.J. Gharib, J.M. Gregg, V.A.I. Huvenne, P. Léonide, X. Li, K. Mangelsdorf, X. Monteys, I. Novosel, S. Sakai, V. Samarkin, K. Sasaki, A.J. Spivack, C. Takashima, A. Tanaka, J. Titschack

\section{References}

Bernecker, M., and Wiedrich, O., 2005. Azooxanthellate corals in the late Maastrictian-early Paleocene of the Danish basin: bryozoan and coral mounds in a boreal shelf setting. In Freiwald, A., and Roberts, M. (Eds.), Cold-water Corals and Ecosystems: Heidelberg (Springer-Verlag), 3-25.

Beyer, A., Schenke, H.W., Klenke, M., and Niederjasper, F., 2003. High resolution bathymetry of the eastern slope of the Porcupine Seabight. Mar. Geol., 198:2754. doi:10.1016/S0025-3227(03)00093-8

De Mol, B., Van Rensbergen, P., Pillen, S., Van Herreweghe, K., Van Rooij, D., McDonnell, A., Huvenne, V., Ivanov, M., Swennen, R., and Henriet, J.-P., 2002. Large deep-water coral banks in the Porcupine Basin, southwest of Ireland. Mar. Geol., 188(1-2):193-231. doi:10.1016/ S0025-3227(02)00281-5

Frederiksen, R., Jensen, A., and Westerberg, H., 1992. The distribution of the scleractinian coral Lophelia pertus $a$ around the Faroe Islands and relation to tidal mixing. Sarsia, 77:157-171.

Henriet, J.-P., De Mol, B., Vanneste, M., Huvenne, V., Van Rooij, D., and the Porcupine-Belgica 97, 98, and 99
Shipboard Parties, 2001. Carbonate mounds and slope failures in the Porcupine Basin: a development model involving fluid venting. In Shannon, P.M., Haughton, P., and Corcoran, D. (Eds.), Petroleum Exploration of Ireland's Offshore Basins. Geol. Soc. Spec. Publ., 188:375-383.

Henriet, J.-P., Guidard, S., and the ODP Proposal 573 Team, 2002. Carbonate mounds as a possible example for microbial activity in geological processes. In Wefer, G., Billet, D., Hebbeln, D., Joergensen, B., and van Weering, Tj. (Eds.), Ocean Margin Systems: Heidelberg (Springer-Verlag), 439-455.

Hovland, M., Mortensen, P.B., Brattegard, T., Strass, P., and Rokengen, K., 1998. Ahermatypic coral banks off mid-Norway: evidence for a link with seepage of light hydrocarbons. Palaios, 13:189-200.

Titschack, J., and Freiwald, A., 2005. Growth, deposition, and facies of Pleistocene bathyal coral communities from Rhodes, Greece. In Freiwald, A., and Roberts, M. (Eds.), Cold-water Corals and Ecosystems: Heidelberg (Springer-Verlag), 61-86.

Van Rooij, D., De Mol, B., Huvenne, V., Ivanov, M., and Henriet, J.-P., 2003. Seismic evidence of current-controlled sedimentation in the Belgica mound province, upper Porcupine slope, SW of Ireland. Mar. Geol., 195(14):31-53. doi:10.1016/S0025-3227(02)00681-3

\section{Authors}

T.G. Ferdelman, Department of Biogeochemistry, MaxPlanck-Institut für Marine Mikrobiologie, Celsiusstrasse 1, 28359 Bremen, Germany, e-mail: tferdelm@mpi-bremen.de

Akihiro Kano, Department of Earth and Planetary Systems Science, Graduate School of Science, Hiroshima University, Kagamiyama 1-3-1, Higashi-hiroshima 739-8526, Japan.

Trevor Williams, Lamont-Doherty Earth Observatory of Columbia University, Borehole Research Group, PO Box 1000, 61 Route 9W, Palisades N.Y. 10964, U.S.A.

and the IODP Expedition 307 Scientists

\section{Related Web Link}

http://iodp.tamu.edu/scienceops/expeditions/exp307.html

\section{Figure Credits}

Fig. 1: 3-D map from Beyer et al., 2003.

Fig. 2: Photo by E. Van der Meersche CMINERAL COLOR VZW

Fig. 3: Mound Seismic from DeMol et al., 2002. 